\title{
RIO-BALDO X RIO-BARDO: AS VEREDAS DO NARRADOR
}

Valéria de Castro Fabrício ${ }^{1}$

Resumo: Este trabalho analisa a obra Grande sertão: veredas, de Guimarães Rosa, partindo da função de seu narrador. Para tanto, embasamo-nos no texto de Walter Benjamim intitulado O narrador, observações sobre a obra de Nikolai Leskow (1983). Entendemos que o discurso de Riobaldo resgata as características definidas por Benjamim como primordiais ao narrador por excelência. Além disso, entendemos que tal elocução, ao mesmo tempo, define o personagem e delineia a sociedade na qual vive.

Palavras-chave: Narrador. Riobaldo. Identidade. Individual. Cultural.

Abstract: This paper analyzes the work Grande sertão: paths Guimarães Rosa starting from his narrator function. Pata both, embasamo us on text Walter Benjamin called The narrator comments on the work of Nikolai Leskow (1983). We understand that Riobaldo speech rescues the characteristics defined by Benjamin as fundamental to the narrator par excellence. Furthermore, we understand that this utterance, while defines the character outlines the society in which he lives.

Key-words: Narrator. Riobaldo. Identity. Individual. Culture.

\section{INTRODUÇÃO}

Este trabalho pretende realizar um estudo acerca da categoria do narrador na obra Grande sertão: veredas, de Guimarães Rosa. Para tanto, tomaremos como referência teórica o texto de Walter Benjamin, O narrador, observações sobre a obra de Nikolai Leskow. Nossa proposta de trabalho parte da análise da abordagem do teórico analisando-a sob a perspectiva do narrador, mais especificamente, a função da narrativa de Riobaldo. Entendemos que sua elocução pode ser analisada sob o aspecto da afirmação de um grupo e de uma cultura específicas.

Primeiro, tomando as prerrogativas de Benjamin, observamos que 0 discurso do ex-jagunço expõe uma leitura de mundo que resgata conhecimentos assimilados ao longo do tempo e de sua experiência e, por isso, reflete valores coletivos. Nessa perspectiva, ele se porta como o narrador

\footnotetext{
${ }^{1}$ Doutoranda em Estudos Literários no Programa de Pós-Graduação em Letras na UFSM. Orientada pela Prof. ${ }^{a}$ Dr. ${ }^{a}$ Rosani Ketzer Umbach. E-mail: valcastrofab@yahoo.com.br
} 
que domina tais verdades e tem, portanto, autoridade para narrá-las e, consequentemente, a responsabilidade de perpetuá-las. Fazendo isso, aproxima-se do narrador primitivo proposto por Benjamim, sintetizado nas imagens do artesão e do marinheiro. Independente da figura que se eleja, a fala deles é responsável por identificar, expor e fixar valores. Eles apresentam quem somos.

Assim, acreditamos ser possível abordar a função da ação narrativa de Riobaldo nessa perspectiva: um relato em que o narrador apropria-se da autoridade para asseverar. Rio-bardo ${ }^{2}$ pergunta na busca da apreensão de seu experienciar o mundo. E a partir dele lega-nos nossa própria identidade coletiva: quem somos.

\section{NARRAR É MUITO PERIGOSO...}

A instância narrativa destinada à locução foi e ainda é intensamente estudada, tanto por sua importância, como por suas múltiplas possibilidades de composição. Não pretendemos nesse estudo aprofundá-la visto que esse não é nosso propósito. Nesse contexto, abordamos sua perspectiva tradicional, portanto a narração de Riobaldo será enfocada como relato em primeira pessoa.

A partir das referências ao ponto de vista, podemos aproximá-lo do narrador qualificado por Benjamim. Para o estudioso alemão, uma das grandes virtudes dele é promover a troca de experiências, o intercâmbio o qual "está em vias de extinção" (1983, p. 197). Seu ensaio data de 1936, vinte anos depois, publica-se Grande sertão: veredas, obra que traz a lume um dos grandes personagens-narradores da literatura. Riobaldo, dotado de singular eloquência, cria na narração uma trama em que os relatos de vivência resultam em troca de experiência: o saber compartilhado. Através de atos e palavras ele se insere e insere-nos no mundo.

\footnotetext{
${ }^{2}$ A adoção do termo Rio bardo foi instituída considerando uma composição partindo do nome original da personagem, mas também, visando explorá-la, posteriormente, em seu sentido semântico. Bardo como trovador, catador popular, narrador de feitos.
} 


\section{RIO-BARDO: O NARRADOR NO MEIO DO REDEMOINHO}

$\mathrm{Na}$ obra, o personagem central, diante de um estrangeiro, empreende uma grande aventura, explicar-Ihe as vicissitudes do sertão. Espaço impar que requisita de compreensão particular. Para fazê-lo, elege como estratégia a narração de sua própria história. Para tanto, necessita organizá-la de maneira apreensível, colocando-a em perspectiva. Tal intento representa o núcleo central da obra, o percurso que abarca sua infância, maturidade e velhice. Por sabê-la resultado de um complexo emaranhado de fios, precisa recorrer a vivências outras, experiências individuais que se imbricaram com a sua, personagens que remontam esse viver coletivo no qual Riobaldo está inserido. Para ele "a vida é mutirão de todos, por todos remexida e temperada" (Rosa, 2001, p. 477).

Desse imenso caldeirão emergem várias outras pequenas narrativas subjacentes que envolvem personagens ligados a sua história. Riobaldo intercala-as no eixo principal da narração para, de forma próxima a parabolar, explicitar o sentido que almeja alcançar. É o que ocorre, por exemplo, quando se refere à história dos filhos de Aleixo "três meninos e uma menina - todos cegados" (Rosa, 2001, p. 28). O narrador menciona-os para ilustrar os ensinamentos de seu compadre Quelemém, espécie de arauto a orientá-lo no campo das coisas misteriosas. Seguindo sua lógica, eles teriam ficado cegos como forma de punição ao pai: "Se sendo castigo, que culpa das hajas do Aleixo aqueles meninozinhos tinham?" (Rosa, 2001, p. 28).

Há nesse trecho três níveis de experiência permeados. Aquela assimilada por Riobaldo nas conversas com seu grande mestre, "meu compadre Quelemém". Há o reconhecimento desse ensino por parte do narrador ao constatá-lo concretizado em seu universo de vivências, e ainda, o intercâmbio deles, ao relatá-lo ao viajante. Tal passagem é emblemática da estratégia narrativa adotada por Riobaldo. Nela, evidenciam-se, recorrentemente, processos de apropriação, vivência e troca de saberes. Mais do que isso, o ex-jagunço absorve o sentido amplo dessas verdades sintetizando-as e, através da sua perspectiva, de seu olhar e voz, tece conclusões. Finaliza o episódio de Aleixo, asseverando "vem o pão, vem a mão, vem o são, vem o cão" (Rosa, 2001, p. 28). 
Benjamim, em seu artigo, ressalta que a crise da narrativa reside no fato de que as experiências não conseguem mais se converter em situações narráveis e isto decorre da falta de vitalidade e de sentido de que as mesmas padecem. Riobaldo é o narrador que inverte essas prerrogativas, pois reconhece sentido no que vivenciou, de tal forma que as organiza à maneira de narração para perpetuá-las. O recurso de síntese dessas experiências é um ponto importante em sua estratégia. Assemelha-se ao conselho. Não o é categoricamente, porque o narrador não ordena explicitamente, antes, lança-a como verdade particular, respaldada pela força da experiência. Não vaticina, mas orienta. Difunde-a para que o ouvinte se aproprie dela, ou não. Aceitandoa, atribua, ele mesmo, seu novo sentido e valor: "remexer vivo o que vim dizendo. Porque não narrei nada à toa: só apontação principal, ao que crer posso. Não esperdiço palavras. O senhor pense o senhor ache. O senhor ponha enredo" (Rosa, 2001, p. 325).

A expressão "remexer vivo o que vim dizendo" revela-nos duas importantes ações desse contador: o lembrar e o refletir. $\mathrm{O}$ apelo à memória $\mathrm{e}$ a tentativa de compreender aquilo que dela emana, confere-lhe experiência e autoridade para narrar. Atributos essenciais do narrador benjaminiano:

\footnotetext{
Raras vezes dá-se conta de que a relação ingênua entre ouvinte e narrador é dominada pelo interesse em reter a coisa narrada. $O$ ponto chave para o ouvinte desarmado é garantir a possibilidade de reprodução. A memória é a capacidade épica por excelência. (Benjamin, 1983, p. 66).
}

O discurso apoiado na força da vivência, amparado pelo resgate da memória e habilitado à reprodução, adquire potência de conselho. Esse só será acatado pelo ouvinte se atribuir, ao sujeito da elocução, credibilidade, se reconhecer nele a voz da sabedoria. Para o teórico alemão "o conselho entretecido na vida vivida é sabedoria" (Benjamin, p. 59). Como diz Riobaldo "Confiança - o senhor sabe -não se tira das coisas feitas ou perfeitas: ela rodeia é o quente da pessoa" (Rosa, 2011, p. 74).

Essa foi adquirida através de um longo percurso de tempo e de vivências. Tal qual o marinheiro, Riobaldo forjou-se através da ação. Ele lançou-se às aventuras de seu tempo, correu riscos, deu-se ao embate. Não o fez só. Na condição de jagunço conheceu os grandes heróis de sua época e 
meio, lutou com eles e por eles. Os príncipes do sertão, com seus feitos, suas incontestáveis verdades incorporaram-se ao "ser" Riobaldo, determinaram seu viver, um viver já superado. Esse privilégio de experiência dota-o de uma singularidade. Reconhecer-se como caudatário de um mundo em extinção. Tal consciência confere-lhe o estatuto de guardião desse passado histórico e lendário, esvanecido no presente. $O$ velho fazendeiro sabe que os grandes personagens que povoam sua lembrança têm merecimento para se perpetuar. Ao encontrar um estrangeiro que desconhece o sertão e suas leis, o narrador reconhece nele um ouvinte apropriado, capaz de compreender a dimensão maior do que relata e sujeito ao estranhamento que desperta o interesse pelo narrado. "Três dias" reitera o ex-chefe de bando, determinando, assim, o tempo da estadia e instaura o tempo da narração.

Ao ouvir tiros ao longe reconhece o mote que instiga o interesse do doutor. "Nonada. Tiros que o senhor ouviu foram de briga de homem, não" (Rosa, 2011, p.33). Dá início ao relato de armas, guerras e feitos, tanto seus quanto daqueles que impregnaram esse sertão que retrata e relata. Tal qual os bardos "poetas e cantores que empregavam o talento para elogiar os príncipes e reis, celebrar feitos de guerra e conservar a memória das linhagens" (Moisés,1974, p.57), Riobaldo conta, lembra, afirma, pergunta, especula, duvida. Organiza a narração sobre uma cambiante estrutura temporal e causal. Ele se permite digressões, tempera-a com sua loquacidade e colore-a com episódios e personagens que ilustram suas verdades e veredas. Resgata um tempo, um espaço, um modelo de vida: o sertão e a jagunçagem. Depositário de uma herança simbólica propagada pela linguagem, atribui-Ihe sentido. Um sentido estranho ao estrangeiro, porque afirma valores milenares: honra, lealdade e justiça sob uma perspectiva única, apreendida apenas em seu contexto, o sertão. Território insulado, à mercê da civilidade urbana. Espaço próprio com sua gente, suas leis. Para explicitá-lo ao forasteiro, elogia seus heróis, celebra suas façanhas, conserva a memória coletiva. Rio-bardo colocase no meio do redemoinho da história e das estórias, numa franca atitude de resistência ante ao apagamento da identidade individual e social. Lembra quem fomos: 
Eu queria decifrar as coisas que são importantes. E estou contando não é uma vida de sertanejo, seja se for jagunço, mas a matéria vertente (...) Assim, é como conto as coisas que foram passado para mim com mais pertença. Vou Ihe falar. Lhe falo do sertão. (Rosa, 2001, p. 1160).

Em seu artigo, Benjamin propõe uma análise acerca da função do narrador, em que pressagia o fim do romance, atribuindo à crise do narrar uma de suas causas primordiais. Seu estudo vaticinou o que hoje vivenciamos. A dificuldade de apreensão das próprias vivências. O narrador por excelência dominava a narração porque compreendia a estrutura explicita e implícita das regras do mundo. Um mundo relativamente dimensionado que conseguia, ainda que de forma frágil, estabelecer verdades porque essas tinham, ou pareciam ter, caráter de perenidade. Grande sertão: veredas lançado vinte anos depois parece reiterar suas assertivas. A obra tem sua estrutura alicerçada na figura do narrador. Todo o restante que se depreende dela advém da elocução respaldada de Riobaldo. Ele trafega pelo externo, pelo social, pelo histórico, pelo cultural para fixar valores, imprescinde da memória. Ao mesmo tempo, em sua incursão individual, revela-nos que as regras do mundo precisam ser apropriadas pelo indivíduo. Esse ato tem o poder de redimensionar as verdades, relativizando-as. Viver é perigoso porque resulta desse inerente intercâmbio: experienciar individualmente o que o mundo nos apresenta como verdade. Equacionar essas duas dimensões, é perigoso.

\section{CONSIDERAÇÕES FINAIS}

Guimarães Rosa e Walter Benjamim partilham da mesma inquietante verdade. Eles detectaram e pressagiaram uma crise aguda do viver. A queda da aura e a desorientação causada pela relativização das verdades geraram na literatura a crise da narração, dos gêneros; na vida, a crise do apreender. Ambos reportam-se ao passado, Benjamin referindo-se a ele como esteio dos grandes modelos narrativos; Guimarães como o suporte de referencialidade onde se cristalizaram nossas verdades. Ambos perceberam um grande perigo a nos rondar, talvez maior do que aquele que conheciam, acenavam para o advento de um tempo no qual viveríamos a incapacidade de configurar verdades. Se para eles a tônica do viver era sua dimensão do perigo, para nós, 
talvez seja a generalização da dúvida... "viver é, mais do que nunca, etcétera" (Rosa, 2001, p.110).

\section{Referências}

ARENDT, Hannah. Ação. Trad. Roberto Raposo. In:

humana. Rio de Janeiro: Forense Universitária, 2005.

A condição

BENJAMIN, Walter. O narrador. Observações acerca da obra de Nicolai Leskow. In: BENJAMIN et al. Os pensadores. São Paulo: abril Cultural, 1983.

MASSAUD, Moisés. Dicionário de termos literários. São Paulo: Cultrix, 1975.

ROSA, João Guimarães. Grande sertão: veredas. 19. ed. Rio de Janeiro: Nova Fronteira, 2001. 